\title{
Tools for Assessing Cardiovascular Disease Risk Factors in Underserved Young Adult Populations: A Systematic Review
}

\author{
Audrey A. Opoku-Acheampong ${ }^{1}{ }^{\oplus}$, Richard R. Rosenkranz ${ }^{1}{ }^{\circledR}$, Koushik Adhikari ${ }^{2}{ }^{\circledR}$, Nancy Muturi $^{3}{ }^{\circledR}$, \\ Cindy Logan ${ }^{4}$ and Tandalayo Kidd ${ }^{1, *}$ \\ 1 Department of Food, Nutrition, Dietetics, and Health, Kansas State University, Manhattan, KS 66506, USA; \\ abampoe@ksu.edu (A.A.O.-A.); ricardo@ksu.edu (R.R.R.) \\ 2 Department of Food Science and Technology, College of Agricultural \& Environmental Sciences, University of \\ Georgia, Griffin, GA 30223, USA; koushik7@uga.edu \\ 3 A. Q. Miller School of Journalism and Mass Communication, Kansas State University, \\ Manhattan, KS 66506, USA; nmuturi@ksu.edu \\ 4 Academic Services, Hale Library, Kansas State University, Manhattan, KS 66506, USA; clogan@ksu.edu \\ * Correspondence: martan@ksu.edu; Tel.: +1-(785)-532-0154
}

check for

updates

Citation: Opoku-Acheampong, A.A.; Rosenkranz, R.R.; Adhikari, K.;

Muturi, N.; Logan, C.; Kidd, T. Tools for Assessing Cardiovascular Disease Risk Factors in Underserved Young Adult Populations: A Systematic Review. Int. J. Environ. Res. Public Health 2021, 18, 13305. https:/ / doi.org/10.3390/ijerph182413305

Academic Editor: Paul B. Tchounwou

Received: 2 November 2021

Accepted: 14 December 2021

Published: 17 December 2021

Publisher's Note: MDPI stays neutral with regard to jurisdictional claims in published maps and institutional affiliations.

Copyright: (c) 2021 by the authors. Licensee MDPI, Basel, Switzerland. This article is an open access article distributed under the terms and conditions of the Creative Commons Attribution (CC BY) license (https:/ / creativecommons.org/licenses/by/ $4.0 /)$.

\begin{abstract}
Cardiovascular disease (CVD, i.e., disease of the heart and blood vessels) is a major cause of death globally. Current assessment tools use either clinical or non-clinical factors alone or in combination to assess CVD risk. The aim of this review was to critically appraise, compare, and summarize existing non-clinically based tools for assessing CVD risk factors in underserved young adult (18-34-year-old) populations. Two online electronic databases-PubMed and Scopus-were searched to identify existing risk assessment tools, using a combination of CVD-related keywords. The search was limited to articles available in English only and published between January 2008 and January 2019. Of the 10,383 studies initially identified, 67 were eligible. In total, 5 out of the 67 articles assessed CVD risk in underserved young adult populations. A total of 21 distinct CVD risk assessment tools were identified; six of these did not require clinical or laboratory data in their estimation (i.e., non-clinical). The main non-clinically based tools identified were the Heart Disease Fact Questionnaire, the Health Beliefs Related to CVD-Perception measure, the Healthy Eating Opinion Survey, the Perception of Risk of Heart Disease Scale, and the WHO STEPwise approach to chronic disease factor surveillance (i.e., the STEPS instrument).
\end{abstract}

Keywords: non-clinical; risk assessment; underserved; young adult

\section{Introduction}

Between 2017 and 2018, approximately 42\% of United States adults aged $\geq 20$ years were obese, with approximately 9\% falling in the class 3 (extreme or severe) obesity category [1]. Obesity is a risk factor for cardiovascular disease (CVD, i.e., disease of the heart and blood vessels), diabetes, and related health conditions, such as coronary heart disease (CHD), heart failure, and stroke [2]. CHD is the narrowing of the inner walls of the blood vessels that transport blood to the heart (arteries) due to a build-up of a waxy substance (plaque) and is the number one cause $(45.1 \%)$ of CVD-related deaths in the U.S., with stroke (16.5\%) and high blood pressure (9.1\%) being the next two highest $[3,4]$. Globally, CVD is the leading cause of death, and in the U.S., it is estimated that one in every three deaths is attributable to CVD [3,5]. It is further projected that by 2030, about 23.6 million deaths will result from CVD events [3].

Cardiovascular risk assessment is necessary for effective CVD prevention intervention, especially in high-risk individuals [6]. Early screening in youth is encouraged to prevent cardiovascular events in adulthood as current evidence suggests that CVD risk factors are even present in adolescence [7]. To date, both paper-based and electronic risk scores have been clinically applied to estimate absolute risks using patients' data and published 
equations. Current risk assessment tools either use family medical history $(\mathrm{FH})$ alone or in combination with clinical factors (e.g., cholesterol level, blood pressure, and glucose level) or non-clinical factors (e.g., gender, race, weight, height, dietary and physical activity) to assess disease risk. However, there are some limitations to these tools, including non-representative or historically dated populations, limited ethnic representation, and narrowly defined and unreliable endpoints [8].

CVD risk scores or algorithms (equations) were originally used in disease diagnoses by health care practitioners, but they could also be used in public health settings as health promotion tools [9]. A non-clinical- or non-laboratory-based assessment tool is particularly useful and a cost-effective option in limited-resource settings, where access to clinical samples or factors may be challenging $[10,11]$. Further, in resource-deficient, ethnic minority and/or underserved communities, where members have less or no health insurance coverage, higher cost barriers to health care access, and poor self-rated general health, disease diagnoses with a family health history or clinical tool may be elusive. Thus, until an illness becomes life-threatening, it may be difficult to detect it and even attempt to control it. $[12,13]$. Previous reviews have identified and evaluated the accuracy of available tools to assess cardiovascular risk factors in general adult populations but not in young adults [14-18]. For example, Gaziano et al. [18] compared non-blood-based and blood-based total cardiovascular risk scores in seven countries and concluded that in terms of performance, both types of risk scores equally predicted risk in the cohorts studied. Chamnan et al. [17] also evaluated the performance of available CVD risk scores used among patients with diabetes and found differences between risk scores originally developed in these individuals compared to those developed in the general population. A recent review by Sacramento et al. [14] described the available methods and assessment tools for the population at high risk of CVD. However, a summary of available CVD risk assessment tools, specifically in young adults, is lacking.

Thus, the primary aim of this review is to critically appraise, compare, and summarize existing non-clinically based tools for assessing CVD risk factors in young adult populations, particularly underserved young adults. Specifically, the objectives are to summarize: (1) the instruments/questionnaires used to assess lifestyle CVD risk factors (i.e., smoking, nutritional behaviors, alcohol use, and physical activity, hereafter referred to as SNAP risk factors) in young adult populations (18-34 years old); (2) the existing instruments to assess risk factors in young adults from underserved populations.

\section{Materials and Methods}

\subsection{Search Strategy}

To avoid creating a redundant review, an initial search for systematic reviews on "cardiovascular disease risk assessment tools" was performed in the Cochrane Database of Systematic Reviews. This yielded 25 Cochrane reviews. A literature search was performed by one of the researchers (A.A.O.A.) in PubMed and Scopus between May and June 2019 to identify studies published in the English language between January 2008 and January 2019. The period from 2008 to 2019 was selected to build upon the evidence obtained from a previous systematic review [15], which spanned studies published from 1 January 1999 to 24 February 2009. The search strategy and keywords used followed guidelines outlined in the COSMIN (Consensus-based Standards for the selection of health status Measurement Instruments) manual for Systematic Reviews of Patient-Reported Outcome Measures (PROMs) [19] as well as those used by Matheny et al. [15]. PubMed and MeSH on Demand version 2.0 were also used to generate a concept table (Table 1) and search terms for the search. A comprehensive search strategy used in PubMed is presented in (Table S1). Reference lists from retrieved full-text articles were also examined for any other potential studies. 
Table 1. Concept table for the literature search.

\begin{tabular}{|c|c|c|c|c|c|}
\hline & Cardiovascular Disease & $\begin{array}{c}\text { Risk } \\
\text { Assessment }\end{array}$ & Tool & Young Adult & $\begin{array}{l}\text { Vulnerable } \\
\text { Populations }\end{array}$ \\
\hline $\begin{array}{c}\text { MeSH } \\
\text { terms/subhead- } \\
\text { ings }\end{array}$ & Cardiovascular Diseases & $\begin{array}{c}\text { Risk } \\
\text { Assessment }\end{array}$ & $\begin{array}{c}\text { Surveys and } \\
\text { questionnaires, } \\
\text { patient-reported } \\
\text { outcome measures, } \\
\text { healthcare surveys }\end{array}$ & Young Adult & $\begin{array}{c}\text { Vulnerable } \\
\text { populations, medically } \\
\text { underserved area }\end{array}$ \\
\hline Text words & $\begin{array}{c}\text { cardiovascular AND } \\
\text { diseases, "cardiovascular } \\
\text { diseases", cardiovascular } \\
\text { AND disease OR } \\
\text { "cardiovascular disease" } \\
\text { heart diseases, heart disease, } \\
\text { cerebrovascular diseases, } \\
\text { hypertension, myocardial } \\
\text { ischemia, myocardial } \\
\text { infarction, heart attack, } \\
\text { cardiovascular stroke, } \\
\text { cerebral hemorrhage, } \\
\text { cerebral stroke, stroke, brain } \\
\text { ischemia }\end{array}$ & $\begin{array}{c}\text { Risk } \\
\text { Assessments, } \\
\text { Health Risk } \\
\text { Assessment, } \\
\text { Health Risk } \\
\text { Assessments, } \\
\text { Risk Factors, } \\
\text { Risk Prediction, } \\
\text { Risk Models, } \\
\text { Risk Prediction } \\
\text { Models }\end{array}$ & $\begin{array}{c}\text { Tools, } \\
\text { instrumentation, } \\
\text { instruments, } \\
\text { community } \\
\text { surveys, surveys, } \\
\text { questionnaires, } \\
\text { "surveys and } \\
\text { questionnaires," } \\
\text { measures, } \\
\text { outcomes } \\
\text { assessment, } \\
\text { outcome measures }\end{array}$ & $\begin{array}{l}\text { young adult, } \\
\text { young adults }\end{array}$ & $\begin{array}{c}\text { Disadvantaged, } \\
\text { Underserved Patients, } \\
\text { Underserved } \\
\text { Populations, Sensitive } \\
\text { Population Groups, } \\
\text { Sensitive Populations, } \\
\text { Medically } \\
\text { Underserved } \\
\text { Population, } \\
\text { vulnerable, limited } \\
\text { [All Fields] AND } \\
\text { health resources [mh] }\end{array}$ \\
\hline
\end{tabular}

\subsection{Eligibility Criteria}

The citations and abstracts from all the retrieved studies were downloaded to Rayyan for Systematic Reviews (a free web/mobile application; https: / www.rayyan.ai/ (accessed on 30 June 2019)) [20] and RefWorks Citation Manager (version 2.1.0.1, Ex Libris, Chicago, IL, USA). Duplicate articles were then deleted. The selection for inclusion into the review was performed by first screening the titles and abstracts and then reviewing the full text of the articles against the inclusion/exclusion criteria outlined in Table 2.

Table 2. Inclusion and exclusion criteria of the review.

\begin{tabular}{lll}
\hline Component & \multicolumn{1}{c}{ Included } & \multicolumn{1}{c}{ Excluded } \\
\hline & & $\begin{array}{l}\text { Studies that did not specify any age range } \\
\text { for participants but only stated a median } \\
\text { or mean age were excluded because it } \\
\text { was difficult to ascertain which age } \\
\text { groups were being discussed. }\end{array}$ \\
& $\begin{array}{l}\text { Studies that recruited only participants } \\
\text { from groups with diagnosed conditions }\end{array}$ \\
& $\begin{array}{l}\text { Specified age range of study participants fell within } \\
\text { the target range of the current study (i.e., 18-34 years) } \\
\text { or if analyses were subdivided by age groups. } \\
\text { Underserved young adults (18-34 years). }\end{array}$ & $\begin{array}{l}\text { linked to the SNAP risk factors (e.g., type } \\
\text { 2 diabetes, hypertension) or from }\end{array}$ \\
& specific/special populations (e.g., severe \\
& mental illness, eating disorders, elite \\
& athletes) as this review was to help select \\
& an appropriate tool (i.e., non-clinically \\
& based) for assessing CVD risk factors in \\
& both symptomatic and asymptomatic \\
& young adults.
\end{tabular}

$\begin{array}{ll}\text { Studies designed to increase CVD risk awareness or prevent } \\ \text { Intervention } & \text { CVD by altering one or more SNAP risk factors or at least }\end{array}$ one CVD outcome.

Comparators Any comparators/controls 
Table 2. Cont.

\begin{tabular}{|c|c|c|}
\hline Component & Included & Excluded \\
\hline Outcome & 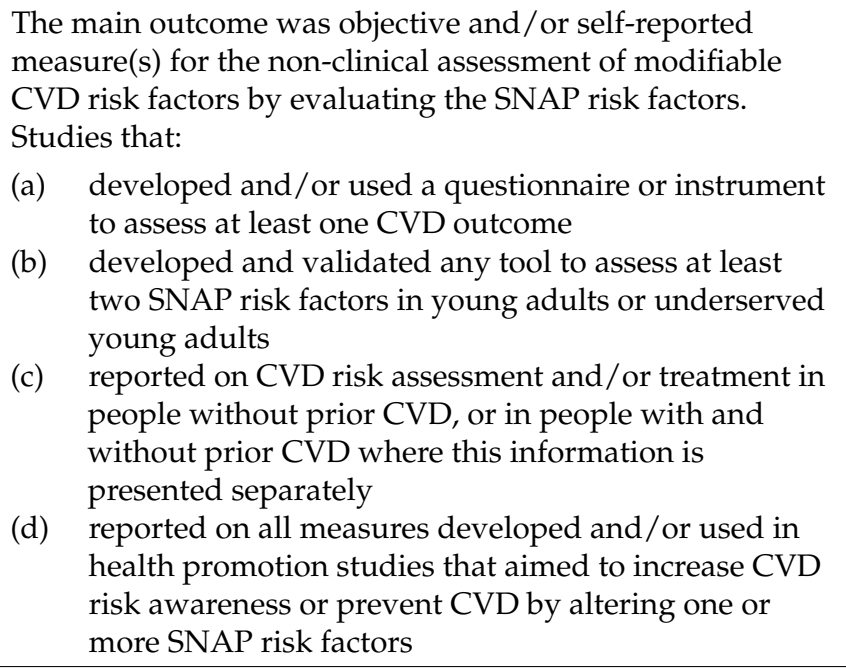 & Articles without full text. \\
\hline Study design & Observational, experimental, and trial studies. & Review/meta-analyses \\
\hline
\end{tabular}

\subsection{Data Extraction}

A data extraction form (Figure S1) was developed to extract the following information: study details (authors, year, country of origin, and study design (e.g., cross-sectional, cohort, etc.)), participants (study population, characteristics, and setting), CVD risk factors (smoking, nutrition, alcohol intake, and physical activity) assessed, CVD risk assessment tools used, and study results/findings. Eligible articles were then classified into two groups based on the two objectives of this review: articles related to CVD risk assessment in the general young adult population, and articles concerning assessment in underserved young adults.

\subsection{Analyses of Results}

The results were summarized by descriptive statistics. A quantitative synthesis of the identified tools was beyond the scope of this review.

\section{Results}

The PRISMA (Preferred Reporting Items for Systematic Reviews and Meta-Analyses) flow chart of the study selection process is presented in Figure 1. The initial search identified a total of 10,383 studies, which was then further limited to full text and abstracts, narrowing the total down to 367 articles. Overall, 67 articles were eligible, 5 of which assessed CVD risk in underserved young adult populations (Figure 1).

\subsection{Studies Assessing CVD Risks in the General Young Adult Population}

Table 3 presents a summary of the included articles that used non-clinical tools to assess CVD risk factors in the general young adult population, including studies that included young adults only as a sub-group analysis of a broader age range of adults.

\subsubsection{Study Designs and Populations}

Most ( $n=40,64 \%$ ) of the included studies were cross-sectional in design (Figure 2). The study populations comprised healthy individuals from both general adult and young adult populations. Almost one-third $(n=19,30.6 \%)$ of the included studies' participants were within the 18-44 and 20-49 years age ranges. 


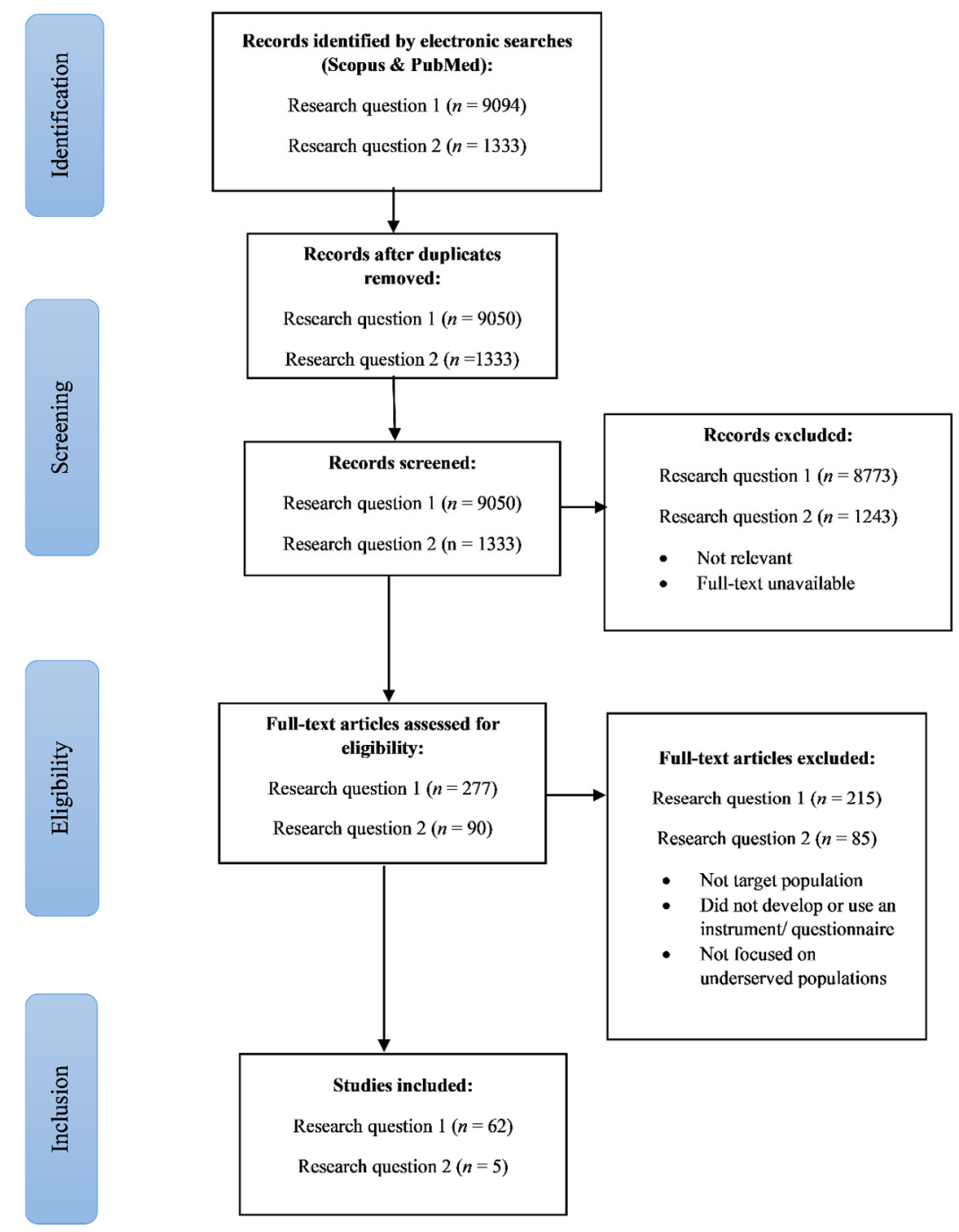

Figure 1. PRISMA flow chart of electronic database search.

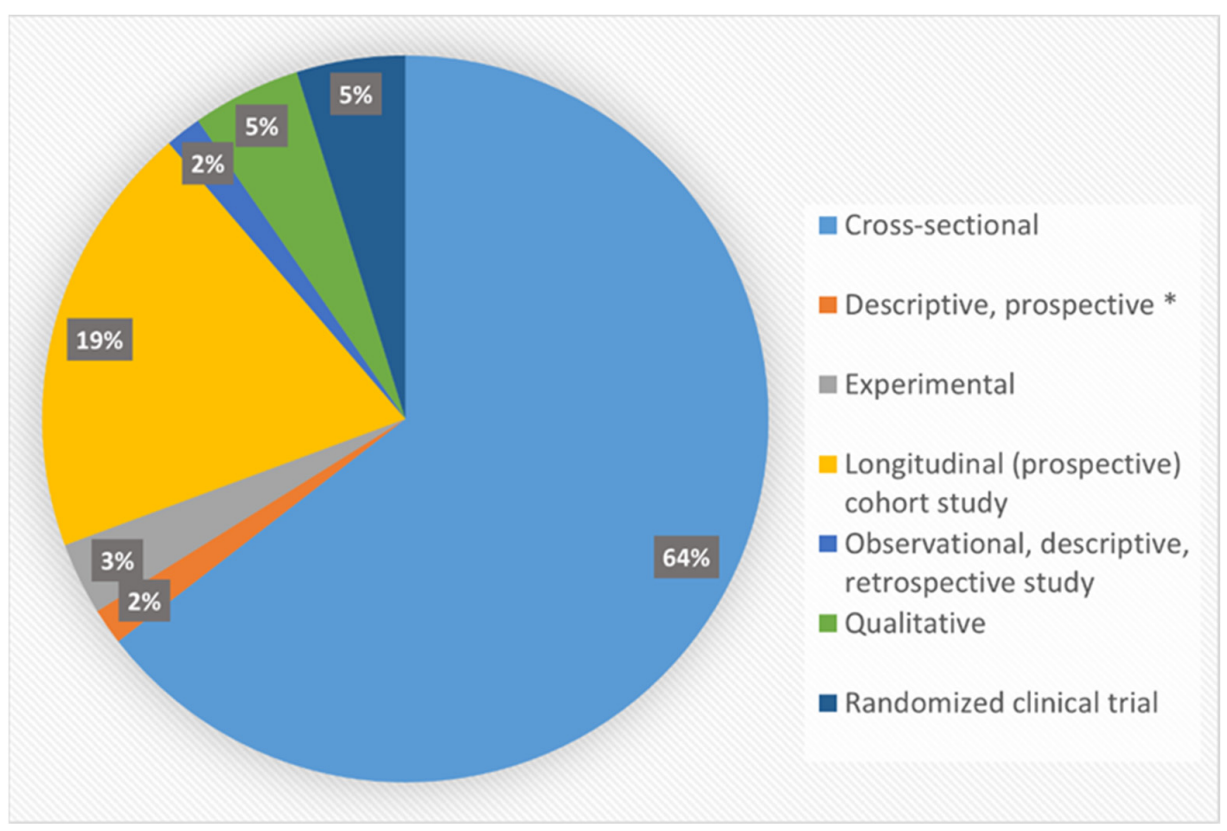

Figure 2. Distribution of included studies by study designs (Note: * Qualitative study). 


\subsubsection{CVD Outcomes}

The assessed CVD outcomes included the prevalence of CVD risk factors (e.g., total cholesterol, high-density lipoprotein cholesterol, and low-density lipoprotein cholesterol), hypertension, $\mathrm{FH}$ of $\mathrm{CVD} / \mathrm{CHD}$, the presence of metabolic syndrome, diabetes, CHD risk, ideal cardiovascular health $(\mathrm{ICH})$ index, the perception of heart disease risk, awareness of lifestyle risk factors, and knowledge of CHD. About half of the studies ( $n=30,48 \%$ ) assessed at least two SNAP risk factors, including six articles that assessed all four SNAP risk factors [21-26]. The most commonly assessed risk factor was smoking $(n=46,74 \%)$, followed by physical activity $(n=33,53 \%)$ and/or nutrition/diet $(n=17,27 \%)$.

Table 3. Summary of included studies that used non-clinical tools for risk assessment in the general young adult population.

\begin{tabular}{|c|c|c|c|c|c|c|c|c|}
\hline No. & $\begin{array}{l}\text { Author(s); Year of } \\
\text { Publication }\end{array}$ & Study Population & Country & $\begin{array}{l}\text { Sample } \\
\text { Size }\end{array}$ & $\begin{array}{l}\text { Age } \\
\text { (Years) }\end{array}$ & Gender & $\begin{array}{l}\text { Modifiable CVD Risk } \\
\text { Factors Assessed } \\
\text { (Smoking, } \\
\text { Nutrition/Diet, Alcohol } \\
\text { Use, or Physical } \\
\text { Activity) }\end{array}$ & $\begin{array}{c}\text { Risk Assessment } \\
\text { Measure/Tool }\end{array}$ \\
\hline 1 & $\begin{array}{l}\text { Williamson W et al., } \\
2018 \text { [27] }\end{array}$ & $\begin{array}{l}\text { Young adults } \\
\text { without clinical } \\
\text { evidence of } \\
\text { cerebrovascular } \\
\text { disease }\end{array}$ & U.K & 125 & $18-40$ & $49 \%$ female & $\begin{array}{c}\text { Smoking, alcohol use, } \\
\text { physical activity }\end{array}$ & $\begin{array}{l}\text { Detailed questionnaire on } \\
\text { medical history, } \\
\text { socioeconomic status, and } \\
\text { self-reported behaviors } \\
\text { such as nutritional intake, } \\
\text { smoking, and alcohol } \\
\text { consumption. }\end{array}$ \\
\hline 2 & $\begin{array}{c}\text { Tran D-T et al., } 2016 \\
\text { [28] }\end{array}$ & $\begin{array}{l}\text { College students at } \\
\text { a Midwestern } \\
\text { institution }\end{array}$ & U.S.A. & 100 & $19-39$ & $\begin{array}{l}\text { Male \& } \\
\text { female * }\end{array}$ & None & $\begin{array}{c}\text { Heart Disease Fact } \\
\text { Questionnaire; The Health } \\
\text { Beliefs Related to } \\
\text { Cardiovascular Disease }\end{array}$ \\
\hline 3 & $\begin{array}{l}\text { Thorpe RJ et al., } 2016 \\
\text { [29] }\end{array}$ & $\begin{array}{l}\text { Participants from } \\
\text { 2000-2009 National } \\
\text { Health Interview } \\
\text { Surveys }\end{array}$ & U.S.A. & 619,130 & $18-75+$ & $\begin{array}{l}52.1 \% \\
\text { female }\end{array}$ & Physical activity & Health survey \\
\hline 4 & Lai HL et al., 2015 [30] & $\begin{array}{l}\text { East Carolina } \\
\text { University } \\
\text { undergraduates }\end{array}$ & U.S.A & 525 & $16-23$ & $\begin{array}{l}60.7 \% \\
\text { female }\end{array}$ & $\begin{array}{l}\text { Smoking, physical } \\
\text { activity }\end{array}$ & $\begin{array}{l}\text { Health survey (internally } \\
\text { validated) }\end{array}$ \\
\hline 5 & $\begin{array}{c}\text { Mark AE et al., } 2014 \\
\text { [31] }\end{array}$ & $\begin{array}{c}\text { Individuals at risk } \\
\text { for coronary heart } \\
\text { disease }\end{array}$ & U.S.A. & 388 & $22-78$ & $\begin{array}{l}60.6 \% \\
\text { female }\end{array}$ & Nutrition/diet & $\begin{array}{c}\text { Questionnaire (the } \\
\text { Healthy Eating Opinion } \\
\text { Survey) }\end{array}$ \\
\hline 6 & $\begin{array}{c}\text { Bloomfield GS et al., } \\
2013 \text { [21] }\end{array}$ & $\begin{array}{l}\text { Adults [Health and } \\
\text { Demographic } \\
\text { Surveillance } \\
\text { System] }\end{array}$ & Kenya & 4037 & $18->64$ & $61 \%$ female & $\begin{array}{c}\text { Smoking, } \\
\text { nutrition/diet, alcohol } \\
\text { use, physical activity }\end{array}$ & $\begin{array}{l}\text { Home-based survey using } \\
\text { the WHO STEPwise } \\
\text { approach to chronic } \\
\text { disease risk factor } \\
\text { surveillance (WHO } \\
\text { STEPS) }\end{array}$ \\
\hline 7 & $\begin{array}{c}\text { Schmitz R et al., } 2012 \\
\text { [32] }\end{array}$ & $\begin{array}{l}\text { Non- } \\
\text { institutionalized } \\
\text { adult population } \\
\text { (National health } \\
\text { interview [GEDA } \\
\text { 2009] respondents. }\end{array}$ & Germany & 21,262 & $18-\geq 65$ & $\begin{array}{l}51.5 \% \\
\text { female }\end{array}$ & $\begin{array}{l}\text { Nutrition/diet, physical } \\
\text { activity }\end{array}$ & $\begin{array}{c}\text { Self-reported } \\
\text { physician-diagnosed } \\
\text { disease }\end{array}$ \\
\hline 8 & $\begin{array}{c}\text { Koura MR et al., } 2012 \\
\text { [33] }\end{array}$ & $\begin{array}{l}\text { Young adult } \\
\text { females }\end{array}$ & $\begin{array}{l}\text { Saudi } \\
\text { Arabia }\end{array}$ & 370 & $\begin{array}{c}\text { Mean = } \\
19.9 \pm 1.4\end{array}$ & $100 \%$ female & $\begin{array}{l}\text { Smoking, } \\
\text { nutrition/diet, physical } \\
\text { activity }\end{array}$ & WHO-STEPS \\
\hline 9 & $\begin{array}{c}\text { Baragou S et al., } 2012 \\
\text { [23] }\end{array}$ & $\begin{array}{l}\text { The general adult } \\
\text { population }\end{array}$ & Togo & 2000 & $18-98$ & $\begin{array}{l}55.1 \% \\
\text { female }\end{array}$ & $\begin{array}{c}\text { Smoking, } \\
\text { nutrition/diet, alcohol } \\
\text { use, physical activity }\end{array}$ & WHO STEPS \\
\hline 10 & $\begin{array}{l}\text { Foulds HJA et al., } 2012 \\
\text { [34] }\end{array}$ & $\begin{array}{l}\text { Aboriginal adult } \\
\text { population } \\
\text { (participants from } \\
\text { the Hearts in } \\
\text { Training and } \\
\text { Health Beat } \\
\text { physical activity } \\
\text { training programs) }\end{array}$ & Canada & 882 & $16-77$ & $\begin{array}{l}75.2 \% \\
\text { female }\end{array}$ & $\begin{array}{l}\text { Smoking, physical } \\
\text { activity }\end{array}$ & Multiple-choice questions \\
\hline 11 & $\begin{array}{c}\text { Chan CW et al., } 2012 \\
\text { [35] }\end{array}$ & $\begin{array}{c}\text { Hong Kong } \\
\text { Chinese population }\end{array}$ & $\begin{array}{l}\text { Hong } \\
\text { Kong }\end{array}$ & 236 & $18-91$ & $\begin{array}{l}66.5 \% \\
\text { female }\end{array}$ & None & Survey \\
\hline 12 & $\begin{array}{c}\text { Maniadakis N et al., } \\
2011 \text { [36] }\end{array}$ & $\begin{array}{l}\text { General adult } \\
\text { population }\end{array}$ & Greece & 3007 & $18->65$ & $\begin{array}{l}51.7 \% \\
\text { female }\end{array}$ & None & Survey \\
\hline 13 & $\begin{array}{l}\text { Al Hamarneh YN } \\
\text { et al., } 2011 \text { [25] }\end{array}$ & $\begin{array}{l}\text { General adult } \\
\text { population }\end{array}$ & $\begin{array}{l}\text { Northern } \\
\text { Ireland }\end{array}$ & 1000 & $20-79$ & $46 \%$ females & $\begin{array}{c}\text { Smoking, } \\
\text { nutrition/diet, alcohol } \\
\text { use, physical activity }\end{array}$ & Questionnaire \\
\hline 14 & $\begin{array}{c}\text { Kuklina EV et al., } 2010 \\
\text { [37] }\end{array}$ & $\begin{array}{l}\text { Participants from } \\
\text { the National } \\
\text { Health and } \\
\text { Nutrition } \\
\text { Examination } \\
\text { Survey (NHANES) }\end{array}$ & U.S.A. & 2587 & $\begin{array}{c}20-35 \\
\text { (male); } \\
20-45 \\
\text { (female) }\end{array}$ & $\begin{array}{l}61.2 \% \\
\text { female }\end{array}$ & Smoking & Survey \\
\hline
\end{tabular}


Table 3. Cont.

\begin{tabular}{|c|c|c|c|c|c|c|c|c|}
\hline No. & $\begin{array}{l}\text { Author(s); Year of } \\
\text { Publication }\end{array}$ & Study Population & Country & $\begin{array}{l}\text { Sample } \\
\text { Size }\end{array}$ & $\begin{array}{c}\text { Age } \\
\text { (Years) }\end{array}$ & Gender & $\begin{array}{l}\text { Modifiable CVD Risk } \\
\text { Factors Assessed } \\
\text { (Smoking, } \\
\text { Nutrition/Diet, Alcohol } \\
\text { Use, or Physical } \\
\text { Activity) }\end{array}$ & $\begin{array}{c}\text { Risk Assessment } \\
\text { Measure/Tool }\end{array}$ \\
\hline 15 & $\begin{array}{c}\text { Wamala JF et al., } 2009 \\
\text { [38] }\end{array}$ & Adult population & Uganda & 842 & $20->75$ & $48 \%$ female & $\begin{array}{c}\text { Smoking, alcohol use, } \\
\text { physical activity }\end{array}$ & Questionnaire \\
\hline 16 & $\begin{array}{l}\text { Bjartveit K et al., } 2009 \\
\text { [39] }\end{array}$ & $\begin{array}{l}\text { Individuals } \\
\text { surveyed for CVD } \\
\text { risk factors }\end{array}$ & Norway & 48,682 & $20-49$ & $\begin{array}{l}51.6 \% \\
\text { female }\end{array}$ & $\begin{array}{l}\text { Smoking, physical } \\
\text { activity }\end{array}$ & Questionnaire \\
\hline 17 & $\begin{array}{c}\text { Tucker AM et al., } 2009 \\
{[40]}\end{array}$ & $\begin{array}{l}\text { Veteran football } \\
\text { players }\end{array}$ & U.S.A. & 504 & $23-35$ & $100 \%$ male & Smoking & Survey instrument \\
\hline 18 & $\begin{array}{c}\text { Sanderson SC et al., } \\
2009[26]\end{array}$ & $\begin{array}{l}\text { Respondents from } \\
\text { the Office of } \\
\text { National Statistics } \\
\text { Omnibus Survey }\end{array}$ & U.K. & 1747 & $16-75$ & $47 \%$ female & $\begin{array}{c}\text { Smoking, } \\
\text { nutrition/diet, alcohol } \\
\text { use, physical activity }\end{array}$ & Questionnaire \\
\hline 19 & Jamil H et al., 2009 [41] & $\begin{array}{l}\text { Respondents from } \\
\text { the Health } \\
\text { Assessment Survey }\end{array}$ & U.S.A. & 3280 & $18-75$ & $\begin{array}{l}71.9 \% \\
\text { female }\end{array}$ & $\begin{array}{l}\text { Smoking, } \\
\text { nutrition/diet, physical } \\
\text { activity }\end{array}$ & Health survey \\
\hline 20 & $\begin{array}{c}\text { Ammouri AA et al., } \\
2008 \text { [42] }\end{array}$ & General population & Jordan & 295 & $15-75$ & $51 \%$ female & None & $\begin{array}{l}\text { Questionnaire (The } \\
\text { Perception of Risk of } \\
\text { Heart Disease Scale) }\end{array}$ \\
\hline
\end{tabular}

* Gender distribution not stated in article. (Note: A survey is a method of data collection and analysis, whereas a questionnaire is a tool or instrument used to collect data; a questionnaire may be a subset of a survey).

\subsubsection{Risk Assessment Tools/Models/Measures}

A total of 21 distinct CVD risk assessment tools were identified from the 62 articles; six of these did not require clinical or laboratory data in their estimation (i.e., non-clinical).

The non-clinically based tools were mostly questionnaires or health surveys and included the Heart Disease Fact Questionnaire (HDFQ), the Health Beliefs Related to CVD-Perception measure (HBCVD), the Healthy Eating Opinion Survey, the Perception of Risk of Heart Disease Scale (PRHDS) and the WHO STEPwise approach to chronic disease factor surveillance (i.e., the STEPS instrument). The HDFQ is a validated and reliable 25 true/false-item questionnaire developed to assess heart disease knowledge among individuals with diabetes [43]. Each questionnaire item is a specific recommendation from at least one of three organizations-the American Diabetes Association, the American Heart Association, and the National Diabetes Education Program. Since the HDFQ assesses heart disease knowledge in people with diabetes, it is heavily skewed on diabetes-related $\mathrm{CHD}$ risk factors. Thus, further testing of its predictive validity is required for other health behaviors such as healthy eating, self-monitoring of blood glucose, or CHD diagnosis [43].

The HBCVD has been used to assess the perceptions of cardiovascular risk factors among individuals with type 2 diabetes. This is a 25 item questionnaire that assesses four constructs of the Health Belief Model (HBM), namely perceived susceptibility and severity of CVD, and benefits and barriers to diet and exercise [44]. However, further reliability testing of this tool is proposed.

The Healthy Eating Opinion Survey is a 43 item questionnaire assessing the psychosocial influences on dietary behavior in individuals at risk for CHD [31]. It was developed based on the Theory of Planned Behavior and assesses one's intention (5 items), attitude toward the behavior (6 items), subjective norm (6 items), perceived behavioral control (5 items), behavior belief (10 items), normative belief (5 items), and control belief (6 items).

The PRHDS is a 20 item instrument developed to measure an individual's perception of his/her heart disease risk in three dimensions- "dread risk", (perceived lack of control, dread, catastrophic potential, and fatal consequences) "risk", (a hazard with few, moderate, known outcomes and consequences) and "unknown risk" (hazards judged to be observable, unknown, new, and delayed in their manifestation of harm) [42].

The STEPS instrument was developed by the WHO for collecting data and measuring non-communicable disease (NCD) risk factors in three sequential levels, or "steps" questionnaire, physical, and biochemical measurements [45]. It includes a core, an expanded, and optional components that provide a framework for countries conducting NCD risk factor surveys and allows each country to choose which of the three steps it will 
implement [45]. Steps 1 and 2 require non-clinical data, whereas step 3 depends on clinical data; thus, the STEPS instrument could be used as either a clinical- or non-clinical risk assessment tool.

The identified clinically based tools were the 10 year and 30 year Framingham Risk Score (FRS), Atherosclerotic CVD (ASCVD) risk calculator, Pathobiological determinants of atherosclerosis in youth (PDAY) risk score, Korean coronary CHD risk score, HellenicSCORE, AHA Ideal Cardiovascular Health (IDEAL) metrics, Progetto CUORE equation, Framingham CHD Prediction Score tool, HeartScore, Framingham risk equations (Joint British Societies 2 [JBS2] risk calculator), and the Systematic Coronary Risk Evaluation (SCORE). The FRS was the most commonly used CVD risk assessment tool in assessments of the young adult population.

\subsubsection{Sample Size}

The number of participants in each of the included studies ranged from 15 to 619,130 $($ median $=2000)$.

\subsection{Studies Assessing CVD Risks in the Underserved Young Adult Populations}

Only five articles were related to CVD risk assessment in underserved young adult populations, and these originated in the U.S. (Table 4).

Table 4. Summary of included studies that assessed CVD risk in underserved young adult populations.

\begin{tabular}{|c|c|c|c|c|c|c|c|c|}
\hline No. & $\begin{array}{c}\text { Author(s); Year of } \\
\text { Publication }\end{array}$ & Study Population & Country & $\begin{array}{l}\text { Sample } \\
\text { Size }\end{array}$ & $\begin{array}{c}\text { Age } \\
\text { (Years) }\end{array}$ & Gender & $\begin{array}{l}\text { Modifiable CVD Risk } \\
\text { Factors Assessed } \\
\text { (Smoking, } \\
\text { Nutrition/Diet, Alcohol } \\
\text { Use, or Physical } \\
\text { Activity) }\end{array}$ & $\begin{array}{c}\text { Risk } \\
\text { Assessment } \\
\text { Measure/Tool }\end{array}$ \\
\hline 1 & $\begin{array}{c}\text { Doom JR et al., } 2017 \\
{[46]}\end{array}$ & $\begin{array}{l}\text { Add Health study } \\
\text { participants }\end{array}$ & U.S.A. & 14,493 & $24-34$ & $\begin{array}{r}48.9 \% \\
\text { female }\end{array}$ & $\begin{array}{l}\text { Smoking, nutrition/diet, } \\
\text { alcohol use, physical } \\
\text { activity }\end{array}$ & $\begin{array}{c}30 \text { year } \\
\text { Framingham } \\
\text { CVD Risk Score }\end{array}$ \\
\hline 2 & $\begin{array}{c}\text { Abshire DA et al., } \\
2016 \text { [47] }\end{array}$ & $\begin{array}{l}\text { Undergraduate } \\
\text { Caucasian males } \\
\text { recruited from a } \\
\text { public, } 4 \text { year } \\
\text { university through } \\
\text { purposive and } \\
\text { snowball sampling; } \\
\text { free of CVD and not } \\
\text { enrolled in a } \\
\text { health-related major. }\end{array}$ & U.S.A. & 10 & $18-25$ & $\begin{array}{l}100 \% \\
\text { male }\end{array}$ & None & Interview guide \\
\hline 3 & $\begin{array}{c}\text { Wickrama KAS et al., } \\
2016 \text { [48] }\end{array}$ & $\begin{array}{l}\text { Add Health study } \\
\text { participants }\end{array}$ & U.S.A. & 8824 & $24-32$ & $\begin{array}{l}\text { Male \& } \\
\text { female * }\end{array}$ & None & $\begin{array}{c}\text { None; } \\
\text { biomarkers } \\
\text { assessed }\end{array}$ \\
\hline 4 & $\begin{array}{c}\text { Khan RJ et al., } 2015 \\
\text { [49] }\end{array}$ & $\begin{array}{l}\text { 1997-2004 data from } \\
\text { National Health } \\
\text { Interview Survey }\end{array}$ & U.S.A. & 121,284 & $18-44$ & $\begin{array}{l}54.5 \% \\
\text { female }\end{array}$ & $\begin{array}{l}\text { Smoking, physical } \\
\text { activity }\end{array}$ & None \\
\hline 5 & $\begin{array}{c}\text { Jamil H et al., } 2009 \\
\text { [41] }\end{array}$ & $\begin{array}{l}\text { Respondents from } \\
\text { the Health } \\
\text { Assessment Survey }\end{array}$ & U.S.A. & 3280 & $18-75$ & $\begin{array}{l}71.9 \% \\
\text { female }\end{array}$ & $\begin{array}{l}\text { Smoking, nutrition/diet, } \\
\text { physical activity }\end{array}$ & Health survey \\
\hline
\end{tabular}

* Gender distribution not stated in the article.

\subsubsection{Study Designs and Populations}

The included articles comprised two cross-sectional studies, two longitudinal studies, and a qualitative (descriptive) study. Except for the qualitative study, the study population fell within the targeted age range (18-34 years, Table 4). Regarding the study populations, all but one study used data from national surveys. 


\subsubsection{CVD Outcomes}

The assessed CVD outcomes included the prevalence of CVD risk factors, cardiometabolic disease risk, the perception of CVD risk, and history of CHD risk factors. Only one [43] out of the five articles assessed all four SNAP risk factors (Table 4).

\subsubsection{Risk Assessment Tools/Models/Measures}

The 30 year Framingham CVD Risk score was the only identified clinically based CVD risk assessment tool. Non-clinically based tools were mostly surveys and questionnaires.

\subsubsection{Sample Size}

The number of participants in each of the included studies ranged from 10 to 121,284 (median $=6052)$.

\section{Discussion}

This systematic literature review aimed to critically appraise, compare, and summarize existing non-clinically based tools for assessing CVD risk factors in young adult populations, particularly underserved young adults. Results showed that most risk assessment tools used in the young adult population were clinically based and included what have been and are still used in middle-aged and older adults, with the FRS tool being the most common one. Additionally, a modified version of the FRS, the 30 year FRS tool, was identified as an assessment tool in a study involving underserved young adults [46]. Unlike the original 10 year FRS, the 30 year FRS tool predicts an individual's risk of developing CVD within 30 years and was specifically designed to be used in the young adult population [50].

The non-clinically based tools identified differed from the five non-laboratory-based cardiovascular risk assessment algorithms identified in a previous review [51]: the Framingham non-laboratory-based method, the Gaziano non-laboratory-based algorithm, the WHO/International Society of Hypertension (WHO/ISH) non-laboratory-based algorithms, the Swedish consultation-based method, and the United Kingdom (UK) General Practice model. The Framingham non-laboratory-based algorithm uses office-based predictors that are obtained in primary care (i.e., age, body mass index (BMI), systolic blood pressure, antihypertensive medication use, current smoking, and diabetes status) to predict 10 year CVD risk [52]. The Gaziano non-laboratory-based algorithm predicts CVD events using age, sex, smoking, diabetes, systolic blood pressure, antihypertensive medication use, and BMI [53]. The WHO/ISH algorithms predict 10-year cardiovascular risk using easily measurable variables, such as gender, systolic blood pressure, smoking status, type 2 diabetes mellitus, and total serum cholesterol [54]. The Swedish consultation-based method predicts cardiovascular risk using age, sex, current smoking, prevalence of diabetes or hypertension at baseline, blood pressure, waist-to-height ratio, and family history of CVD. The UK General Practice model uses age, systolic blood pressure, smoking habit, and self-rated health to predict 10 year CVD risk in older women [55].

Unlike previously identified tools, the non-clinically based tools identified in this review either assessed an individual's knowledge or perception of heart disease risk. They did not directly assess one's CVD risk in relation to the four SNAP risk factors.

The timely identification of young adults at high risk for CVD will help to reduce risk factor burden [56]. However, the selected age range in this review (i.e., 18-34 years) differs from that of the samples used in previous studies. For example, Alssema et al. [9] used a sample of adults aged 28-85 years to develop a single non-laboratory-based model for predicting three cardio-metabolic diseases, CVD, type 2 diabetes, or chronic kidney disease, in three different population cohorts. Additionally, in the study by Jamil et al. [41], the 18-39 years age group was the least represented; thus, the authors suggested using a relatively younger sample to make the findings more generalizable.

Furthermore, the five previously mentioned non-laboratory-based risk assessment tools relied on varied samples of middle-aged and older adults [51]. For instance, the 
Framingham non-laboratory-based algorithm was derived from an adult sample aged 30-74 years [52]; the Gaziano non-laboratory-based algorithm used an ethnically and racially diverse sample of 25-74-year-old adults [18,53]; the Swedish consultation-based method was derived from a sample of Swedish adults aged 40-59 years; and the UK General Practice model used only women aged 60-79 years [54]. Further validation of these non-laboratory-based tools in diverse populations is recommended to improve their performance and applicability in the screening and management of CVD in limited-resource settings [51].

Considering that the non-clinical risk assessment tools identified in this review were developed to assess CVD risks, none assessed all four SNAP risk factors together. The knowledge assessed with HDFQ pertained to smoking, healthy eating, and physical activity in relation to heart disease, as well as the relationship between diabetes and heart disease. Unlike the HDFQ, the HBCVD and the PRHDS do not assess a specific health behavior in relation to CVD risk, but an individual's health beliefs in a likely CVD event and CVD risk perceptions, respectively. It was not surprising that smoking was the most commonly assessed SNAP risk factor in the included studies, considering most of the existing CVD risk scores use an individual's smoking status as a predictor in their calculations $[14,16]$. An individual's knowledge and perception may provide some useful information about an individual's behavior but may not necessarily predict their CVD risk. Thus, incorporating all four SNAP risk factors in a non-clinically based CVD risk assessment tool may provide a broader picture of disease risk.

\section{Strengths and Limitations}

A major strength of the present review is that it used a concept table in combination with a previously used search strategy that was thorough enough to identify the existing tools in adult populations. To the best of our knowledge, this is the first systematic review to identify tools or instruments that have been used to assess CVD risk factors in the young adult population. However, there are a few limitations. The number of articles excluded due to full-text unavailability might have caused an indirect omission of relevant details, especially from studies published in other languages. The grey literature was not searched even though it could have also been a useful source of other non-laboratory-based risk assessment tools.

\section{Conclusions}

This review provides a summary of non-clinically based CVD risk assessment tools used in the general young adults and underserved young adult populations. The findings indicated that generally, there were only a few objective and/or self-reported measure(s) for the non-clinical assessment of modifiable CVD risk factors among young adults. The main non-clinically based tools identified were the Heart Disease Fact Questionnaire, the Health Beliefs Related to CVD-Perception measure, the Healthy Eating Opinion Survey, the Perception of Risk of Heart Disease Scale, and the WHO STEPwise approach to chronic disease factor surveillance (i.e., the STEPS instrument). The identified tools assessed individuals' knowledge or perception of heart disease risk but did not directly assess their CVD risk in relation to the four SNAP risk factors (i.e., smoking, nutrition behaviors, alcohol use, and physical activity). Future studies could adapt items from the identified non-clinically based CVD risk assessment tools, incorporating the four SNAP risk factors to develop a non-clinically based risk assessment tool, and validate it in young adults. 
Supplementary Materials: The following are available online at https: / www.mdpi.com/article/ 10.3390/ijerph182413305/s1, Table S1: Search strategy used in Pubmed, Figure S1: Sample of data extraction form used.

Author Contributions: Conceptualization, A.A.O.-A.; methodology, A.A.O.-A. and T.K.; formal analysis, A.A.O.-A.; investigation, A.A.O.-A.; data curation, A.A.O.-A. and T.K.; writing-original draft preparation, A.A.O.-A.; writing-review and editing, T.K., R.R.R., K.A., N.M. and C.L.; visualization, A.A.O.-A.; supervision, T.K.; project administration, A.A.O.-A. All authors have read and agreed to the published version of the manuscript.

Funding: This research received no external funding.

Data Availability Statement: No new data were created or analyzed in this study. Data sharing is not applicable to this article.

Conflicts of Interest: The authors declare no conflict of interest.

\section{References}

1. Hales, C.M.; Carroll, M.D.; Fryar, C.D.; Ogden, C.L. Prevalence of Obesity and Severe Obesity among Adults: United States, 2017-2018 NCHS Data Brief, No 360; National Center for Health Statistics: Hyattsville, MD, USA, 2020.

2. Kumanyika, S.K.; Obarzanek, E.; Stettler, N.; Bell, R.; Field, A.E.; Fortmann, S.P.; Franklin, B.A.; Gillman, M.W.; Lewis, C.E.; Poston, W.C., II; et al. Population-Based Prevention of Obesity: The Need for Comprehensive Promotion of Healthful Eating, Physical Activity, and Energy Balance: A Scientific Statement from American Heart Association Council on Epidemiology and Prevention, Interdisciplinary Committee for Prevention (formerly the expert panel on population and prevention science). Circulation 2008, 118, 428-464. [CrossRef]

3. Benjamin, E.J.; Blaha, M.J.; Chiuve, S.E.; Cushman, M.; Das, S.R.; Deo, R.; De Ferranti, S.D.; Floyd, J.; Fornage, M.; Gillespie, C.; et al. Heart Disease and Stroke Statistics'2017 Update: A Report from the American Heart Association. Circulation 2017, 135, e146-e603. [CrossRef]

4. Sandmaier, M. The Healthy Heart Handbook for Women; National Heart, Lung, \& Blood Institute: Bethesda, MD, USA, 2007; pp. 1-127.

5. Ferdinand, K.C.; Armani, A. Cardiovascular Disease in Racial and Ethnic Minorities. Totowa, N.J., Ed.; Humana Press: New York, NY, USA, 2006; pp. 1-21. [CrossRef]

6. Pletcher, M.J.; Moran, A.E. Cardiovascular Risk Assessment. Med. Clin. N. Am. 2017, 101, 673-688. [CrossRef]

7. Gooding, H.C.; de Ferranti, S.D. Cardiovascular Risk Assessment and Cholesterol Management in Adolescents: Getting to the Heart of the Matter. Curr. Opin. Pediatr. 2010, 22, 398-405. [CrossRef] [PubMed]

8. Goff, D.; Lloyd-Jones, D.; Bennett, G.; Coady, S.; D’Agostino, R.; Gibbons, R.; Greenland, P.; Lackland, D.; Levy, D.; O'Donnell, C.; et al. 2013 ACC/AHA Guideline on the Assessment of Cardiovascular Risk: A Report of the American College of Cardiology/American Heart Association Task Force on Practice Guidelines. Circulation 2014, 129, S49-S73. [CrossRef]

9. Alssema, M.; Newson, R.S.; Bakker, S.J.L.; Stehouwer, C.D.A.; Heymans, M.W.; Nijpels, G.; Hillege, H.L.; Hofman, A.; Witteman, J.C.M.; Gansevoort, R.T.; et al. One Risk Assessment Tool for Cardiovascular Disease, Type 2 Diabetes, and Chronic Kidney Disease. Diabetes Care 2012, 35, 741-749. [CrossRef]

10. Ofori, S.; Odia, O. Risk Assessment in the Prevention of Cardiovascular Disease in Low-Resource Settings. Indian Heart J. 2016, 68, 391-398. [CrossRef] [PubMed]

11. World Health Organization. Prevention of Cardiovascular Disease: Guidelines for Assessment and Management of Total Cardiovascular Risk; World Health Organization: Geneva, Switzerland, 2007.

12. McFayden, E. Key Factors Influencing Health Disparities Among African Americans. Race Gend. Class New Orleans 2009, 16, 120-133. [CrossRef]

13. Centers for Disease Control and Prevention. Surveillance of Health Status in Minority Communities-Racial and Ethnic Approaches to Community Health Across the U.S. (REACH U.S.) Risk Factor Survey, United States, 2009. Morb. Mortal. Wkly. Rep. Surveill. Summ. 2011, 60,1-44.

14. Sacramento-Pacheco, J.; Duarte-Clíments, G.; Gómez-Salgado, J.; Romero-Martín, M.; Sánchez-Gómez, M.B. Cardiovascular Risk Assessment Tools: A Scoping Review. Aust. Crit. Care 2019, 32, 540-559. [CrossRef]

15. Matheny, M.; McPheeters, M.; Glasser, A.; Mercaldo, N.; Weaver, R.; Jerome, R.; Walden, R.; McKoy, J.; Pritchett, J.; Tsai, C. Systematic Review of Cardiovascular Disease Risk Assessment Tools; Agency for Healthcare Research and Quality: Rockville, MD, USA, 2011.

16. Cooney, M.-T.; Dudina, A.L.; Graham, I.M. Value and Limitations of Existing Scores for the Assessment of Cardiovascular Risk: A Review for Clinicians. J. Am. Coll. Cardiol. 2009, 54, 1209-1227. [CrossRef]

17. Chamnan, P.; Simmons, R.K.; Sharp, S.J.; Griffin, S.J.; Wareham, N.J. Cardiovascular Risk Assessment Scores for People with Diabetes: A Systematic Review. Diabetologia 2009, 52, 2001-2015. [CrossRef] 
18. Gaziano, T.A.; Abrahams-Gessel, S.; Alam, S.; Alam, D.; Ali, M.; Bloomfield, G.; Carrillo-Larco, R.M.; Dorairaj, P.; Gutierrez, L.; Irazola, V.; et al. Comparison of Nonblood-Based and Blood-Based Total CV Risk Scores in Global Populations. Glob. Heart 2016, 11,37-46.e2. [CrossRef]

19. Prinsen, C.A.C.; Patrick, D.L.; Alonso, J.; Bouter, L.M.; de Vet, H.C.W.; Terwee, C.B. COSMIN guideline for systematic reviews of patient-reported outcome measures. Qual. Life Res. 2018, 27, 1147-1157. [CrossRef]

20. Ouzzani, M.; Hammady, H.; Fedorowicz, Z.; Elmagarmid, A. Rayyan-a Web and Mobile App for Systematic Reviews. Syst. Rev. 2016, 5, 1-10. [CrossRef] [PubMed]

21. Bloomfield, G.S.; Mwangi, A.; Chege, P.; Simiyu, C.J.; Aswa, D.F.; Odhiambo, D.; Obala, A.A.; Ayuo, P.; Khwa-Otsyula, B. Multiple Cardiovascular Risk Factors in Kenya: Evidence from a Health and Demographic Surveillance System Using the WHO STEPwise Approach to Chronic Disease Risk Factor Surveillance. Heart 2013, 99, 1323-1330. [CrossRef]

22. Altenburg, T.M.; de Kroon, M.L.A.; Renders, C.M.; Hirasing, R.; Chinapaw, M.J.M. TV Time but Not Computer Time Is Associated with Cardiometabolic Risk in Dutch Young Adults. PLoS ONE 2013, 8, e57749.

23. Baragou, S.; Djibril, M.; Atta, B.; Damorou, F.; Pio, M.; Balogou, A. Prevalence of Cardiovascular Risk Factors in an Urban Area of Togo: A WHO STEPS-Wise Approach in Lome, Togo. Cardiovasc. J. Afr. 2012, 23, 309-313. [CrossRef] [PubMed]

24. Zhang, H.; Rodriguez-Monguio, R. Racial Disparities in the Risk of Developing Obesity-Related Diseases: A Cross-Sectional Study. Ethn. Dis. 2012, 22, 308-317. [PubMed]

25. Hamarneh, N.Y.A.; Crealey, G.E.; McElnay, J.C. Coronary Heart Disease: Health Knowledge and Behaviour. Int. J. Clin. Pharm. 2011, 33, 111-124. [CrossRef]

26. Sanderson, S.C.; Waller, J.; Jarvis, M.J.; Humphries, S.E.; Wardle, J. Awareness of Lifestyle Risk Factors for Cancer and Heart Disease among Adults in the UK. Patient Educ. Couns. 2009, 74, 221-228. [CrossRef]

27. Williamson, W.; Lewandowski, A.J.; Forkert, N.D.; Griffanti, L.; Okell, T.W.; Betts, J.; Boardman, H.; Siepmann, T.; McKean, D.; Huckstep, O.; et al. Association of Cardiovascular Risk Factors with MRI Indices of Cerebrovascular Structure and Function and White Matter Hyperintensities in Young Adults. J. Am. Med. Assoc. 2018, 320, 665-673. [CrossRef] [PubMed]

28. Tran, D.M.T.; Zimmerman, L.M.; Kupzyk, K.A. Validation of the Knowledge and Perception of Cardiovascular Risk Factors Questionnaires for College Students. J. Nurs. Meas. 2016, 24, 202-214. [CrossRef] [PubMed]

29. Thorpe, R.J.J.; Fesahazion, R.G.; Parker, L.; Wilder, T.; Rooks, R.N.; Bowie, J.V.; Bell, C.N.; Szanton, S.L.; LaVeist, T.A. Accelerated Health Declines among African Americans in the USA. J. Urban Health 2016, 93, 808-820. [CrossRef]

30. Lai, H.L.; Ward, R.; Bolin, P. Cardiovascular Health of North Carolina Undergraduates. N. C. Med. J. 2015, 76, 286-292. [CrossRef] [PubMed]

31. Mark, A.E.; Riley, D.L.; McDonnell, L.A.; Pipe, A.L.; Reid, R.D. Healthy Eating Opinion Survey for Individuals at Risk for Cardiovascular Disease. Health Psychol. 2014, 33, 904-912. [CrossRef]

32. Schmitz, R.; Jordan, S.; Müters, S.; Neuhauser, H. Population-Wide Use of Behavioural Prevention and Counselling Programmes for Lifestyle-Related Cardiovascular Risk Factors in Germany. Eur. J. Prev. Cardiol. 2012, 19, 849-857. [CrossRef] [PubMed]

33. Koura, M.R.; Al-Dabal, B.; Rasheed, P.; Al-Sowielem, L.; Makki, S.M. Prehypertension among Young Adult Females in Dammam, Saudi Arabia. East. Mediterr. Health J. 2012, 18, 728-735. [CrossRef] [PubMed]

34. Foulds, H.J.A.; Bredin, S.S.D.; Warburton, D.E.R. An Evaluation of the Physical Activity and Health Status of British Columbian Aboriginal Populations. Appl. Physiol. Nutr. Metab. 2012, 127-137. [CrossRef]

35. Chan, C.W.; Leung, S.F. Differences in Perceptions of Coronary Disease among Hong Kong Chinese: Implications for the Societal Readiness in Disease Prevention. Psychol. Health Med. 2012, 17, 366-376. [CrossRef]

36. Maniadakis, N.; Kourlaba, G.; Fragoulakis, V. Self-Reported Prevalence of Atherothrombosis in a General Population Sample of Adults in Greece; a Telephone Survey. BMC Cardiovasc. Disord. 2011, 11, 16. [CrossRef]

37. Kuklina, E.V.; Yoon, P.W.; Keenan, N.L. Prevalence of Coronary Heart Disease Risk Factors and Screening for High Cholesterol Levels among Young Adults, United States, 1999-2006. Ann. Fam. Med. 2010, 8, 327-334. [CrossRef]

38. Wamala, J.F.; Karyabakabo, Z.; Ndungutse, D.; Guwatudde, D. Prevalence Factors Associated with Hypertension in Rukungiri District, Uganda-A Community-Based Study. Afr. Health Sci. 2009, 9, 153-161. [PubMed]

39. Bjartveit, K.; Tverdal, A. Health Consequences of Sustained Smoking Cessation. Tob. Control 2009, 18, 197-206. [CrossRef]

40. Tucker, A.M.; Vogel, R.A.; Lincoln, A.E.; Dunn, R.E.; Ahrensfield, D.C.; Allen, T.W.; Castle, L.W.; Heyer, R.A.; Pellman, E.J.; Strollo, P.J.; et al. Prevalence of Cardiovascular Disease Risk Factors among National Football League Players. J. Am. Med. Assoc. 2009, 301, 2111-2119. [CrossRef] [PubMed]

41. Jamil, H.; Dallo, F.; Fakhouri, M.; Templin, T.; Khoury, R.; Fakhouri, H. The Prevalence of Self-Reported Chronic Conditions among Arab, Chaldean, and African Americans in Southeast Michigan. Ethn. Dis. 2009, 19, 293-301.

42. Ammouri, A.A.; Neuberger, G. The Perception of Risk of Heart Disease Scale: Development and Psychometric Analysis. J. Nurs. Meas. 2008, 16, 83-98. [CrossRef]

43. Wagner, J.; Lacey, K.; Chyun, D.; Abbott, G. Development of a Questionnaire to Measure Heart Disease Risk Knowledge in People with Diabetes: The Heart Disease Fact Questionnaire. Patient Educ. Couns. 2005, 58, 82-87. [CrossRef]

44. Tovar, E.G.; Rayens, M.K.; Clark, M.; Nguyen, H. Development and Psychometric Testing of the Health Beliefs Related to Cardiovascular Disease Scale: Preliminary Findings. J. Adv. Nurs. 2010, 66, 2772-2784. [CrossRef]

45. World Health Organization (WHO). WHO STEPS Surveillance Manual: The WHO STEPwise Approach to Chronic Disease Risk Factor Surveillance; World Health Organization: Geneva, Switzerland, 2008. 
46. Doom, J.R.; Mason, S.M.; Suglia, S.F.; Clark, C.J. Pathways between Childhood/Adolescent Adversity, Adolescent Socioeconomic Status, and Long-Term Cardiovascular Disease Risk in Young Adulthood. Soc. Sci. Med. 2017, 188, 166-176. [CrossRef] [PubMed]

47. Abshire, D.A.; Lennie, T.A.; Moser, D.K.; Mudd-Martin, G.T. Perceptions Related to Cardiovascular Disease Risk in Caucasian College Males. Am. J. Mens. Health 2016, 10, N136-N144. [CrossRef]

48. Wickrama, K.A.S.; Bae, D.; O'Neal, C.W. Black-White Disparity in Young Adults' Disease Risk: An Investigation of Variation in the Vulnerability of Black Young Adults to Early and Later Adversity. J. Adolesc. Health 2016, 59, 209-215. [CrossRef]

49. Khan, R.J.; Stewart, C.P.; Davis, S.K.; Harvey, D.J.; Leistikow, B.N. The Risk and Burden of Smoking Related Heart Disease Mortality among Young People in the United States. Tob. Induc. Dis. 2015, 13, 16. [CrossRef] [PubMed]

50. Pencina, M.J.; D’Agostino Sr, R.B.; Larson, M.G.; Massaro, J.M.; Vasan, R.S. Predicting the 30-Year Risk of Cardiovascular Disease: The Framingham Heart Study. Circulation 2009, 119, 3078-3084. [CrossRef]

51. Kariuki, J.K.; Stuart-Shor, E.M.; Leveille, S.G.; Hayman, L.L. Evaluation of the Performance of Existing Non-Laboratory Based Cardiovascular Risk Assessment Algorithms. BMC Cardiovasc. Disord. 2013, 13, 123. [CrossRef] [PubMed]

52. D'Agostino Sr, R.B.; Vasan, R.S.; Pencina, M.J.; Wolf, P.A.; Cobain, M.; Massaro, J.M.; Kannel, W.B. General Cardiovascular Risk Profile for Use in Primary Care: The Framingham Heart Study. Circulation 2008, 117, 743-754. [CrossRef] [PubMed]

53. Gaziano, T.A.; Young, C.R.; Fitzmaurice, G.; Atwood, S.; Gaziano, J.M. Laboratory-Based versus Non-Laboratory-Based Method for Assessment of Cardiovascular Disease Risk: The NHANES I Follow-up Study Cohort. Lancet 2008, 371, 923-931. [CrossRef]

54. Mendis, S.; Lindholm, L.H.; Mancia, G.; Whitworth, J.; Alderman, M.; Lim, S.; Heagerty, T. World Health Organization (WHO) and International Society of Hypertension (ISH) Risk Prediction Charts: Assessment of Cardiovascular Risk for Prevention and Control of Cardiovascular Disease in Low and Middle-Income Countries. J. Hypertens. 2007, 25, 1578-1582. [CrossRef]

55. May, M.; Lawlor, D.A.; Brindle, P.; Patel, R.; Ebrahim, S. Cardiovascular Disease Risk Assessment in Older Women: Can We Improve on Framingham? British Women's Heart and Health Prospective Cohort Study. Heart 2006, 92, 1396-1402. [CrossRef]

56. Berry, J.D.; Lloyd-Jones, D.M.; Garside, D.B.; Greenland, P. Framingham Risk Score and Prediction of Coronary Heart Disease Death in Young Men. Am. Heart J. 2007, 154, 80-86. [CrossRef] 